\title{
EFFECT OF ETHANOL EXTRACT OF LEAF OF CAJANUS INDICUS SPRENG IN CARBON TETRACHLORIDE INDUCED HEPATOPATHY IN RATES IN RELATION TO FREE RADICAL SCAVENGING ACTION
}

\author{
Majumdar Biswajit, Sinha Arun Kumar and Yadav Shrawan
}

\begin{abstract}
:
Phytochemicals, that is, chemicals present in various plants and herbs, are now becoming important candidates for development of drugs. Wide range of medicinals plants $\{$ Plants from which potential photochemicals are isolated for development of drugs for treatment of diseaseslpresent in South Asian countries have now been increasingly utilized for development of phytomedicines. Treatment with ethanol extract of leaf of Cajanus indicus Spreng at a dose of $50 \mathrm{mg} / \mathrm{kg}$ body weight for 20 days, after induction of hepatotoxic damage by $\mathrm{CCl}_{4}$, produce significant elevation of the hepatic injury. The liver marker enzymes like(Aspartate Transaminate) AST, GGT(Gamma Glutamyl Transferase), ALT(Alanine Transaminase) and ALP(Alkaline Phosphatase) decreased significantly at the above dose showing the optimum effect against hepatic damage. The liver antioxidant enzymes SOD, catalase, glutathione peroxidase, glutathione reductase and glutathione transferase and the membrane damaging indicators TBARS(Thiobarbituric Acis Reactive Species), conjugate diene and marker of glutathione status indicate the mechanism of healing action to be due to scavenging of free radicals or ROS. The results thus gives a confirmatory proof that the healing action of ethanol extract of leaf of Cajanus indicus Spreng is for shifting of equilibrium from the peroxidant to antioxidant side and the leaf acts as a natural antioxidant and healer of $\mathrm{CCl}_{4}$ induced hepatotoxicity.
\end{abstract}

Key words: Cajanus indicus Spreng; $\mathrm{CCl}_{4}$; Hepatotoxicity, Antioxidant.

\section{Introduction:}

The leaf of Cajanus indicus Spreng (Leguminosae family) which is commonly known as arhar pata in Bengali is a widely grown plant in large parts of India and South-West Asian countries, particularly in the regions of subtropical humid climate. In the Indian traditional system of medicine. Extract of leaf of Cajanus indicus Spreng has been reported to have prominent healing effects against trauma, and significant hepatoprotective and anti-inflammatory activity ${ }^{1-3}$. However no systematic scientific investigations have been done to understand the biochemical mechanism of action. As the extract of the leaf has been found to give relief against liver diseases particularly Hepatitis A while the liver injury has been proven to be due to damage by free radicals or reactive oxygen species (ROS) $)^{3,4}$. Hence the present study was undertaken to evaluate the curative effect of leaf extract against $\mathrm{CCl}_{4}$ induced hepatic injury and to elucidate any relation with its antioxidant activity.

Materials and Methods:

Plant material

Leaves of Cajanus indicus Spreng were collected from the local market in Kolkata in the months of November-December. Authenticity was established by experts of Botanical Survey of India, Shibpur , Hawrah. The leaves were thoroughly washed in water and then soaked in $900 \mathrm{ml}$ of $95 \%$ ethanol for 7 days with intermittent shaking. On the $8^{\text {th }}$ day, the whole material was filtered through nylon mesh. The 
filtrate was collected and concentrated under reduced pressure. The residual solvent was removed under vacuum in a rotary evaporator and the solid brownish red mass obtained $(8.7 \% \mathrm{w} / \mathrm{w})$ was kept in a vacuum desiccator at $4^{0} \mathrm{C}$ until used for further studies.

\section{Animal and treatment:}

Healthy, pathogen free, colony bred, adult male Charles Foster rats (150-200g) were used in this experiments. The animals were housed in environmentally controlled rooms $\quad\left(25 \pm 1^{0} \mathrm{C}\right)$ with $12 \mathrm{hr}: 12 \mathrm{hr}$ light: dark schedule and fed with pellet food (Hindustan Lever, India) ad libitum and had free access to water. All chemicals used were of analytical grade. Chemicals were purchased either from Sigma Chemicals Co. (St Louis, MO, USA) or E-Merck (Germany) and SRL (India).

Animals were divided into following 3 groups of 6 animals each.

Group 1: Controls, which received subcutaneously liquid paraffin (lp) twice a week at the dose of $3 \mathrm{ml} / \mathrm{kg}$ body weight.

Group II: The animals in which liver damage was indicated by subcutaneous administration of $\mathrm{CCl}_{4}(0.1 \mathrm{ml} / 100 \mathrm{~g}$ body weight) $+1 p$ twice a week.

Group III: Animals were the same as in Group II above. Additonally they received the ethanol extract daily at the dose of 50 $\mathrm{mg} / \mathrm{Kg}$ body weight as suspension in $1 \mathrm{ml}$ water orally.

The animals were kept for 20 days. Animals were fasted over night on the $19^{\text {th }}$ day and were sacrificed on day 20 by decapitation .Blood was collected from incision of jugular vein and serum was prepared from the collected blood. The liver was dissected out, rinsed in phosphate saline buffer ( $\mathrm{pH}$ 7.4) and immediately preceded for biochemical estimations.

The measurement of thiobarbituric acid reactive substances (TBARS) was done as an index of lipid peroxide (LPO) , conjugated diene(CD) content was found out by the method of Klein ${ }^{6}$. The activity of superoxide dismutase (SOD), one of the most prominent antioxidant enzymes in the eukaryotic defense machinery against ROS damage was determined by the method of McCord and Fridovich ${ }^{7}$. The assay procedure involved the inhibition of epinephrine auto oxidation in an alkaline medium (pH 10.2).

The enzyme activity was expressed in arbitrary units considering 50\% inhibition in the reaction mixture under the experimental condition as one unit of SOD. Catalase activity was determined according to the method of Luck et $a l^{8}$. Reduced glutathione (GSH) or the total sulphhydryl group was measured according to the method of Ellman with minor modifications. Glutathione peroxidase (GPX) was assayed by the method of Rotruck et $a l^{10}$. Glutathione transferase (GTS) and glutathione reductase (GRD) were assayed by the methods of Habig et al ${ }^{11}$ and Racker ${ }^{12}$.

Statistical analysis was carried out using Analysis of Variance (ANOVA) test followed by using Student " $t$ " tests to estimate the level of significance among the mean \pm SE values in different groups of animals. 


\section{Results and Discussion:}

Table 1: Effects of Ethanol extract of leaf of Cajanus Indicus Spreng on the antioxidant status.

\begin{tabular}{|c|c|c|c|}
\hline Parameters & Group I & GroupII & GroupIII \\
\hline $\begin{array}{c}\text { Thiobarbituric acid reactive species } \\
{[\mu \mathrm{M} / \mathrm{mg} \text { protein }],}\end{array}$ & $1.36 \pm 0.04$ & $0.76 \pm 0.04$ & $1.14 \pm 0.26$ \\
\hline $\begin{array}{c}\text { Diene Conjugate } \\
(\mu \mathrm{M} / 100 \mathrm{~g} \text { tissue }), .\end{array}$ & $0.28 \pm 0.05$, & $84 \pm 0.08$, & $0.33 \pm 0.09$ \\
\hline $\begin{array}{c}\text { Reduced glutathione } \\
(\mu \mathrm{M} / 100 \mathrm{~g} \text { tissue }),\end{array}$ & $366.2 \pm 19.83$, & $\begin{array}{c}206.1 \pm 5.5 \\
7\end{array}$ & $\begin{array}{c}324.0 \pm 34 . \\
94\end{array}$ \\
\hline
\end{tabular}

Values are mean \pm SEM of 6 animals in each group.

$* \mathrm{P}<0.01$ as compared to group.

$* * \mathrm{P}<0.001$ as compared to group I

Table 2: Effect of Ethanol extract of leaf of Cajanus indicus Spreng on activity of ROS (Reactive Oxygen Species) scavenging enzymes

\begin{tabular}{|c|c|c|c|}
\hline Parameters & $\begin{array}{c}\text { Group } \\
\text { I }\end{array}$ & $\begin{array}{c}\text { Group } \\
\text { II }\end{array}$ & $\begin{array}{c}\text { Group } \\
\text { III }\end{array}$ \\
\hline Superoxide dismutase (U/mg protein) & $\begin{array}{l}15.98 \pm 1.5 \\
9\end{array}$ & $7.64 \pm 0.94$ & $11.55 \pm 0.77$ \\
\hline Catalase (U/mg protein) & $7.56 \pm 0.78$ & $4.40 \pm 0.85$ & $7.08 \pm 0.88$ \\
\hline $\begin{array}{c}\text { Glutathione Peroxidase (U/mg } \\
\text { protein) }\end{array}$ & $0.85 \pm 0.09$ & $0.50 \pm 0.01$ & $0.73 \pm 0.05$ \\
\hline Glutathione Reductase (U/mg protein) & $6.71 \pm 0.39$ & $3.02 \pm 0.15$ & $6.01 \pm 0.36$ \\
\hline $\begin{array}{l}\text { Glutathione transferase }(\mu \mathrm{M} / \mathrm{mg} \\
\text { protein) }\end{array}$ & $8.50 \pm 0.34$ & $16.05 \pm 1.04$ & $8.63 \pm 0.48$ \\
\hline
\end{tabular}

Values are mean \pm SEM of 6 animals in each group.

$* \mathrm{P}<0.01$ as compared to group

$* * \mathrm{P}<0.001$ as compared to group I 
Table 3: Percentage of hepatoprotection offered by ethanol extract of leaf of Cajanus Indicus Spreng in respect of liver marker enzymes.

\begin{tabular}{|c|c|c|c|c|}
\hline $\begin{array}{l}\text { Treatment } \\
\text { (mg/ } \\
\text { kg body } \\
\text { weight) }\end{array}$ & $\begin{array}{c}\text { Percentage of } \\
\text { relative } \\
\text { decrease of enzyme } \\
\text { markers }\end{array}$ & & & \\
\hline & $\begin{array}{c}\text { AST } \\
\text { (Aspartate } \\
\text { Transaminase) }\end{array}$ & $\begin{array}{c}\text { GGT } \\
\text { (Gamma } \\
\text { Glutamyl } \\
\text { Transferase) } \\
\end{array}$ & $\begin{array}{c}\text { ALT } \\
\text { (Alanine } \\
\text { Transferas } \\
\text { e) } \\
\end{array}$ & $\begin{array}{c}\text { ALP } \\
\text { (Alkaline } \\
\text { Phosphatase) }\end{array}$ \\
\hline 25 & $20.76 \pm 1.60$ & $17.90 \pm 1.20$ & $20.21 \pm 1.17$ & $15.73 \pm 1.48$ \\
\hline 50 & $9.82 \pm 0.87$ & $8.10 \pm 0.62$ & $8.83 \pm 1.06$ & $7.48 \pm 0.74$ \\
\hline 75 & $27.07 \pm 3.33$ & $18.37 \pm 1.36$ & $15.57 \pm 1.97$ & $18.28 \pm 1.12$ \\
\hline 100 & $69.50 \pm 5.41$ & $62.84 \pm 2.27$ & $74.15 \pm 1.77$ & $66.78 \pm 3.03$ \\
\hline
\end{tabular}

Values are mean \pm SEM of 6 animals in each group.

$* \mathrm{P}<0.01$ as compared to group

$* * \mathrm{P}<0.001$ as compared to group I

The study reveals the hepatoprotective action of the medicinal plant and that phytochemicals present in the plant are responsible for the above action, which can well be utilized for development of antihepatotoxic drug. The action of the phytochemicals is due to the antioxidant action, as now free radicals[Species with unpaired electrons produced by various biochemical reactionswithin the body] have been found to be the underlying cause of various diseases from hepatic injury, gastric ulcer, heart diseases and immunological reactions. The ethanolic extract of leaf of Cajanus Indicus Spreng exhibited significant protection against
$\mathrm{CCl}_{4}$-induced hepatic damage, as is evident from the various biochemical parameters related to the hepatic conditions in Eukaryotic system.

Treatment with $\mathrm{CCl}_{4}$-induced significant damage and the effect of $\mathrm{CCl}_{4}$ has now been established to be due to the reactive oxygen species (ROS) .As is evident from the decrease in level of the antioxidant enzymes.The level of the liver marker enzymes decreased within the range of $25-100 \mathrm{mg} / \mathrm{Kg}$ body weight in case of treated animals as compared to untreated control. 
That the prooxidant antioxidant balance is essential in free radical mediated injuries in eukaryotes is now being emerged as a vital alternative $^{13,14,15}$ to the long termed and established medical theories. Oxygen toxicity and resultant generation of most aggressive reactive oxygen species (ROS) result in consequent tissue damage and necrosis.

$\mathrm{CCl}_{4}$ mediated hepatotoxic injury, have taken as a model for liver injury is established by the mechanism of $\mathrm{CCl}_{4}$ accumulated in hepatic parenchymal cells and metabolically activated by cytochrome $\mathrm{P}-450$ dependent mono oxygenases to form a trichloromethyl free radical $\left(\mathrm{CCl}_{3}\right.$.). Thus alkylating cellular proteins and other related biological macromolecules with a simultaneous attack on polyunsaturated fatty acids and with a consequent formation of lipid peroxides leading to hepatic damage.

The study reveals that leaf of Cajaus indicus Spreng at a dose of $50 \mathrm{mg} / \mathrm{kg}$ body weight maximally protects hepatic damage caused by $\mathrm{CCl}_{4}$ and the mechanism is believed to be due to free radical scavenging one. The results involving aspartate aminotransferase (AST), alanine aminotransferase (ALT), alkaline phosphatase (ALP) and gamma glutamyl transpeptidase (GGT) confirms the proposal of protective mechanism. The SOD, CAT, GPX and GRD, which maintains the intricate balance of prooxidant antioxidant ratio, are increased showing the utility of balance towards antioxidant side is a major healing indication.

\section{References:}

1. Chatterjee A, Pakrashi SC. Treatise of Indian Medicinal Plants. Vol.1 (Publication \& Information Directorate, CSIR, New Delhi). 1995; 78.
Elevated level of TBARS and CD observed in $\mathrm{CCl}_{4}$-treated animals indicates excessive formation of free radicals and activation of LPO system resulting in hepatic damage. TBARS produced as byproducts of LPO that occurs in hydrophobic core of biomembranes. The significant decline in these concentrations of these constituents in the liver tissue of extract of leaf of Cajanus indicus Spreng administration rats indicates anti-lipid peroxidative effect of the leaf extract.

GSH is a major non-protein thiol in living organisms, which plays a central role in co-ordinating the body's antioxidant defense processes. Perturbation of GSH status of a biological system has been reported to lead to serious consequences. Decline in GSH content in the liver of $\mathrm{CCl}_{4}$-intoxicated rats, and its subsequent return towards near normalcy in extract of leaf of Cajanus indicus Spreng treated rats reveal antioxidant effect of the leaf extract.

Explanations of the possible mechanism underlying the hepatoprotective properties of drugs include the prevention of GSH depletion and destruction of free radicals. GTS also plays an essential role in liver by eliminating toxic compounds by conjugating them with glutathione. GRD is concerned with the maintainance of cellular level of GSH (especially in the reduced state) by effecting fast reduction of oxidized glutathione to reduced glutathione. Thus it can be concluded that a possible healing action of extract of leaf of Cajanus indicus Spreng and the mechanism is by free radicals scavenging pathway of the plant extract.

2. Prasad VS, Venkatachalam SR, Romesh C, Paul Thomas. Dietary antioxidant natural defence against disease. Aryavaidyan, 1999; 12 (3): 149 . 
3 Bhattacharya S. Chiranjeev Vanaushadhi. Vol.1. Ananda Publishers, 1997; 76

4. Chun-Chun Lin, Ming Hong Yen, Tsae Shiuam Lo and Jer Min Lin. Evaluation of the hepatoprotective and antioxidant activity of Bochmeria niveavar nivea and $B$, Involver tenacissma.J Ethnopharmacol. 1999; 64: 141.

5. Yagi K. Lipid peroxide and Human disease. Chem Phys Lipids. 1987; 45: 337.

6. Klein RA. The detection of oxidation in lyposomal preparations. Biochem Biophys Acta. 1983; 210: 486

7. McCord JM, FridovchI. Super oxide dismutase, an enzymatic function for erythrocuprein(hemocuprein). J Biol Chem. 1969; 244: 6649.

8. Luck H, Catalase. In : Methods in Enzymatic Analysis. Bergmeyer HU (Ed).Verlay Chemical, Academic press, New York. 1963; 885.

9. Ellmann GL. Issue sulfhydryl groups. Arch Biochem Biophys. 1959; 82; 70.

10. Rotruck JT, Pope AL and Gautter HE, Selenium. Biochemical roles as a Component of glutathione peroxidase. Sc. 1973; 179: 588

11. Habig WH, Pabst MJ and Jakpoby WB. Glutathione transferase: A first Enzymatic step in mercapturic acid formation. J Biol Chem. 1974; 249: 7130.

12. Racker E. Glutathione reductase (Liver and Yeast) In: Methods in Enzymology, (Eds) Colowick, S.P.and Kaplan N.O. Academic Press. New York. 1955; 7 : 722 .
13. Jer-Min Lin, Chin-Ching Lin, Mineng Chen, Takashi Ujiie and Atsushi Takada. Radical scavenger and anti hepatotoxic activity of Ganodema formosanum, Ganoderma lucidum and Ganoderma neojaponicum. J thnopharmacol. 1975; 47: 33.

14. Sarwat Sultana, Shahid Pervaiz, Mohammed Iqbal and Mohammed Athar.Crude extracts of hepatoprotective plants, Solanum nigrum and Cichorum Intybus inhibit free radical- mediated DNA damage. J Ethnopharmacol. 1995; 45: 189.

15. Castro JA, Ferrya JC, Castro CR, Sesame H, Fenos OM and Gillette JR. Prevention of carbon tetrachloride induced necrosis by inhibitors of drug metabilosm. Further studies on the echanism of their action. Biochem. Pharmacol. 1974: 23: 295.

16. Beautler E and Kelley BM. The effects of Sodium nitrate on red cell glutathione. Experimentia. 1963; 19: 96.

17. Das UN, Kumar KV, Krishnamohan L. Lipid peroxidation, EFA in patients With diabetes mellitus and diabetes nephopathy. J Nut Med. 1985; 4: 149.

18. Olsen CE. Glutathione modulates toxic oxygen metabolite injury of canine chief cell culture in primary culture. Am J Physiol. 1988; 254: 249.

19. Constantinescu A, Han D and Packer L. Vitamin E recycling in human erythrocyte membrane. J Biol Chem. 1993; 268: 1090-6.

20. Majumdar B, Ray Chowdhuri S, Ray A and Bandyopadhyay SK. Potent antiulcerogenic activity of ethanol extract of leaf of Piper Beetle Linn by antioxidative mechanism. Ind $\mathrm{J}$ Clin Biochem. 2002; 17: 49. 
21. Bandyopadhyay U, Das D, Banerjee RK. Reactive oxygen species; oxidative damage and pathogenesis. Curr Sc. 1999; 77 (5): 658.
22. Hetil O. Mechanism of free radicals in gastrointestinal and liver disease. Clin Biochem. 1993; 134: 1347.

Biswajit Majumdar, Associate Professor; A. K. Sinha, associate Professor and Srawan Kumar. Yadav, Lecturer, Department of Biochemistry, Nobel Medical College and Teaching Hospital, Biratnagar, Nepal. Address for Correspondence: Dr. Biswajit Majumdar, E-mail:biswajitmajumdar2005@yahoo.ca 